\title{
Trends and Policy Correlates of Agricultural Production and Agricultural Production Sustainability Outcomes in Ghana and Nigeria
}

\author{
Olawale Emmanuel Olayide ${ }^{1,2}$, Isaac Kow Tetteh ${ }^{2} \&$ Labode Popoola $^{1}$ \\ ${ }^{1}$ Centre for Sustainable Development, University of Ibadan, Nigeria \\ ${ }^{2}$ Department of Theoretical and Applied Biology, Kwame Nkrumah University of Science and Technology, \\ Ghana \\ Correspondence: Olawale Emmanuel Olayide, Centre for Sustainable Development, University of Ibadan, \\ Nigeria. E-mail: oeolayide@knust.edu.gh, oe.olayide@ui.edu.ng, waleolayide@yahoo.com
}

\author{
Received: September 4, 2015 Accepted: September 28, 2015 Online Published: October 29, 2015 \\ doi:10.5539/jsd.v8n9p71 \\ URL: http://dx.doi.org/10.5539/jsd.v8n9p71
}

\begin{abstract}
This paper analysed policy correlates of agricultural production and agricultural production sustainability outcomes in Ghana and Nigeria. It underscores the influence of political systems and international development agendas as correlates of agricultural production and agricultural production sustainability outcomes. This is to the extent of providing evidence policy on agricultural production and agricultural production sustainability outcomes. Ghana and Nigeria have comparable farming/agricultural system and policy environment. Data used for the analyses spanned five decades. Trends analysis and inferential statistics were employed. The results revealed that policy correlates can contribute to the current discourse in sustainable development agenda and to resolving the dilemma of agricultural policy implementation for sustainable agricultural development, especially in Ghana and Nigeria. The findings reinforce the need for appropriate policies in transforming the agricultural sector while ensuring sustainable development outcomes.
\end{abstract}

Keywords: Agricultural production, sustainability outcomes, policy correlates

\section{Introduction}

Agricultural policy is a transforming process that shapes or enables sustainable agricultural production and agricultural development outcomes (DFID, 1999). Agricultural production promotes broad-based economy development especially for agriculture-based developing economies like Ghana and Nigeria (World Bank, 2008). Besides, agriculture is a catalyst to exiting poverty, and transforming the agriculture-based economies (World Bank, 2008). The agricultural policy documents of Ghana and Nigeria identify the sector as engine of growth and sustainable economic transformation (FGN, 2001; MOFA, 2007).

Economic development propositions and trajectories in Africa have always underscored the need for agriculture-led development to solving the challenges of industrial growth, rural-urban migration, conflicts and overall economic development. Agricultural growth and its accompanying positive growth linkages have wide-ranging impacts on overall growth and incomes of the poor (Dorosh \& Mellor, 2013; World Bank, 2008; Hazell \& Ramaswamy, 1991). Others (Manyong et al., 2005) have argued that the peasant nature of agricultural production system, with its low productivity, poor response to technology adoption strategies, and poor return of investment impede sustainable agricultural growth and development. Thus, suggesting that agricultural policy strategies promote equitable resource redistribution, sustainable growth and development thereby ensuring overall welfare improvement of the citizenry. According to Dorosh \& Mellor (2013), a high rate of agricultural growth has far-reaching positive implications for the economic development of low-income countries in terms of increasing employment and accelerating poverty reduction.

The growing world's population imposes an increasing impact of the human footprint on agricultural production (in terms of outputs of agriculture or yields) and agricultural production sustainability outcomes (defined as agricultural production per human population or agricultural production per capita). Recent studies reveal that although agricultural production per capita has improved globally, there exist regional and national differences with low level of outcomes in Africa (Kitzes et al., 2008; Hazell \& Wood, 2008; Pretty, 2008). 
There are general agreements that agricultural policies create enabling environment for sustainable agricultural production (DFID, 1999; Manyong et al., 2005; Olayide \& Ikpi, 2013; Mockshell \& Birner, 2015). The operating policy environments, including domestic-based, donor-based or global development-based scenarios, also impact policy outcomes (Olayide \& Ikpi, 2013; Mockshell \& Birner, 2015). Past and recent studies have examined the relative contributions of domestic and donor perspectives to agricultural policies, (Binswanger \& Deininger, 1997; Garba, 1999; Akinyosoye, 2005; Banful \& Olayide. 2010; Ayanwale, 2011) as well as the role of political actions on agricultural policy choices (Grindle \& Thomas, 1989; Goldstein \& Keohane, 1993; Orren, 1988; Sabatier \& Jenkins-Smith, 1993; Böcher, 2012; Mockshell \& Birner, 2015), including how such policy instruments could be used more strategically and effectively (Jayne \& Rashid, 2013; Mockshell \& Birner, 2015). The general conclusion from literature is that agricultural policies could facilitate or hinder agricultural growth and sustainable development.

Further, direct and indirect agricultural policies instruments have been used in Ghana and Nigeria (Manyong et al., 2005; Birner \& Resnick, 2010; Benin et al., 2012; Olayide \& Ikpi, 2013; Mockshell \& Birner, 2015) since 1960s. The political economy of the support for the implementation of policy strategies includes the provision of subsidies on agricultural inputs, product prices, and infrastructural supports (Olayide \& Ikpi, 2013; Takeshima \& Liverpool-Tasie. 2015; Mockshell \& Birner, 2015). Government support and protection for agriculture are evident by the high level nominal rate of assistance for agriculture in Nigeria and Ghana (Anderson, 2009; Anderson \& Masters. 2009; Brooks et al., 2009; Anderson, 2010; Anderson et al., 2013; Mockshell \& Birner, 2015).

There are further evidences on the interactions of political systems and agricultural protection (Swinnen, 2010). It has been observed that the pattern of agricultural support in Africa has since shifted from taxation (Krueger et al., 1991) to increasing support, and in some cases, resulting in overshooting of agricultural support (Anderson, 2009; Anderson \& Masters, 2009; Mockshell \& Birner, 2015). Although this form of overshooting of agricultural policy is often criticized, there is need to understand the preference of such policy framework with a view to proffering alternative policy options especially when it comes to the issue of ensuring sustainability outcomes of agricultural production. We know that policy issues on agriculture are not easy to resolve (Mockshell \& Birner, 2015). But there is the need to ensure successful implementation of agricultural policy in order to prevent cycles of agriculture policy failures and crises that lead to underdevelopment of both the agricultural sector as well as national and regional economies in Africa (Van de Walle, 2001; Jayne et al., 2002; Jayne \& Rashid, 2013; Takeshima \& Liverpool-Tasie. 2015; Mockshell \& Birner, 2015). It is on this background that this paper analysed the policy correlates of agricultural production and agricultural production sustainability outcomes using comparable case study countries - Ghana and Nigeria. This paper contributes to emerging literature on correlates of agricultural sustainability outcomes (Ikpi, 1995; Diao et al., 2014) and the imperatives of agricultural policies in the transformation of African economies through the agricultural sector (World Bank, 2008; Takeshima \& Liverpool-Tasie, 2015; Mockshell \& Birner, 2015).

This paper does not analyse specific agricultural policy instruments (e.g., inputs policy or price policy); but rather provide insights on the effect of aggregate overarching policy operating framework on agricultural production sustainability outcomes for Ghana and Nigeria, which are the two largest economies in West Africa. Agricultural production sustainability outcomes as used in this paper are agricultural production indices adjusted for human population in respective countries to obtain the agricultural production per capita indices. The analysis is to the intent of informing policy prescriptions for post-2015 sustainable development agenda.

\section{Materials and Methods}

\subsection{Study Area and Coverage}

The case study countries are Nigeria and Ghana. Both countries share similar agricultural/farming systems (Sebastian, 2014; Garrity et al., 2012; Dixon et al., 2001). The shared agricultural systems are: root and tuber crop, cereal-root crop mixed, humid lowland tree crop, and fish-based. According to Sebastian (2014), populations within the same farming system share similar farming practices and livelihood strategies. It could be emphasized that many farming systems in Africa exhibit a strong geographical pattern, extending across northern Africa and Africa south of the Sahara (SSA), reflecting a mix of factors, including climate, soils, and markets. Broadly similar farming systems share recognizable livelihood patterns and similar development pathways, and agricultural policy strategies (FGN, 2001; MOFA, 2007; Sebastian, 2014). It is in the context of the similarities between Ghana and Nigeria that we analyse the trends and policy correlates of agricultural production and sustainability outcomes.

\subsection{Data and Sources}

Comparable time series dataset on indices of agricultural production and agricultural production sustainability 
outcomes were sourced from the website of the Food and Agricultural Organisation of the United Nations (FAO) via http://faostat3.fao.org/download/Q/QI/E. The indices of agricultural production were gross production index and net production index, while the indices of agricultural production sustainability outcomes were gross per capita production index and net per capita production index. We identified policy scenarios based on shared economic and political experience of the two case countries. The policy scenarios are political systems (military or democratic rule) and implementation of international development agenda (pre-millennium development goals (MDGs) era, 1961-1999 or millennium development goals era, 2000-2012). All data spanned from 1961 to 2012. We analysed and compared the indices of agricultural production and agricultural production sustainability outcomes in the context of these policy scenarios.

\subsection{Analytical Techniques}

Descriptive statistics (including means and standard deviations) and inferential statistical models (analysis of variance, one-way ANOVA) were employed, and operationalized using Statistical Package for the Social Sciences (SPSS) software. The choice of ANOVA as analytical inferential statistics was informed because of the need to test for statistical significance of the policy scenarios in the two case countries. The factor variables (countries and policy scenarios) are in categorical levels of measurement (dummies). Agricultural production and agricultural production sustainability outcomes were obtained as indices (quantitative data) while policy scenarios, including the political systems and the MDGs, and time trends (decadal) were computed as binary or dummy variables (qualitative data). This categorization of variables was done to bridge the gap in empirical analysis and recent literature on agricultural policy analysis that used qualitative and quantitative approaches (Takeshima \& Liverpool-Tasie, 2015; Mockshell \& Birner, 2015). The analysis also benefits from explaining the general patterns of change in agricultural production sustainability outcomes over space and time with a view to contributing to better understanding of their interactions, including domestic and global initiatives.

\section{Results}

The results (see Tables 1 and 2) show that time trends, political system and the millennium development goals (MDGs) influenced the indices of agricultural production (gross production and net production) as well as agricultural production sustainability outcomes (gross per capita production and net per capita production). The indices of agricultural production and agricultural production sustainability outcomes were correlated with time trends, political system and the MDGs era for Ghana.

Specifically, Ghana performed better than Nigeria consistently from 1961 to 1980 . The performances were also statistically significant $(\mathrm{p}<0.05)$. The results further revealed that although Ghana performed better that Nigeria during the 1961 to 1980 , the performance was not sustainable over the entire study period when all the indices are considered. In cases where Nigeria performed better that Ghana (especially 1991-2000), such performances were not statistically significant. Overall, the per capita indices of agricultural production were the most important factors that explained the better performance recorded by Ghana over Nigeria. Hence, the results seem to suggest consistent implementation of agricultural policies in Ghana over the study period (1961-2012) which could have enhanced better performance of the agricultural production sustainability outcomes (see Table 1). 
Table 1. Trends in the indices of agricultural production and sustainability outcomes

\begin{tabular}{|c|c|c|c|c|}
\hline Period & Indicators & Ghana & Nigeria & $\begin{array}{l}\text { Better performing } \\
\text { country }\end{array}$ \\
\hline \multirow[t]{4}{*}{ 1961-1970 } & Gross per capita production index & $85.19(3.49)$ & $72.17(4.59)$ & Ghana** \\
\hline & Net Production Index & $31.08(2.58)$ & $26.58(3.11)$ & Ghana** \\
\hline & Net per capita Production Index & $85.63(3.61)$ & $72.71(4.09)$ & Ghana** \\
\hline & Gross Production Index & $30.93(2.63)$ & $26.39(3.32)$ & Ghana** \\
\hline \multirow[t]{4}{*}{$1971-1980$} & Gross per capita production index & $75.07(12.23)$ & $60.52(6.72)$ & Ghana** \\
\hline & Net Production Index & $34.35(3.86)$ & $28.43(1.26)$ & Ghana** \\
\hline & Net per capita Production Index & $75.14(12.27)$ & $61.53(6.13)$ & Ghana** \\
\hline & Gross Production Index & $34.32(3.84)$ & $27.93(1.40)$ & Ghana** \\
\hline \multirow[t]{4}{*}{$1981-1990$} & Gross per capita production index & $60.44(5.25)$ & $58.12(6.85)$ & Ghana \\
\hline & Net Production Index & $36.32(5.46)$ & $36.58(6.77)$ & Nigeria \\
\hline & Net per capita Production Index & $60.11(5.19)$ & $59.48(6.34)$ & Ghana \\
\hline & Gross Production Index & $36.52(5.51)$ & $35.77(7.02)$ & Ghana \\
\hline \multirow[t]{4}{*}{$1991-2000$} & Gross per capita production index & $84.59(6.31)$ & $86.72(4.40)$ & Nigeria \\
\hline & Net Production Index & $67.16(9.77)$ & $68.74(8.67)$ & Nigeria \\
\hline & Net per capita Production Index & $84.41(6.47)$ & $86.92(4.56)$ & Nigeria \\
\hline & Gross Production Index & $67.29(9.66)$ & $68.56(8.50)$ & Nigeria \\
\hline \multirow[t]{4}{*}{ 2001-2012 } & Gross per capita production index & $102.65(7.12)$ & $92.42(5.81)$ & Ghana \\
\hline & Net Production Index & $107.57(17.18)$ & $96.98(8.84)$ & Ghana \\
\hline & Net per capita Production Index & $102.72(7.39)$ & $92.89(5.56)$ & Ghana \\
\hline & Gross Production Index & $107.47(16.85)$ & $96.45(8.70)$ & Ghana \\
\hline \multirow[t]{4}{*}{$1961-2012$} & Gross per capita production index & $82.40(15.98)$ & $74.70(15.08)$ & Ghana** \\
\hline & Net Production Index & $57.31(32.06)$ & $53.21(29.19)$ & Ghana \\
\hline & Net per capita Production Index & $82.42(16.14)$ & $75.41(14.63)$ & Ghana** \\
\hline & Gross Production Index & $57.31(31.99)$ & $52.77(29.19)$ & Ghana \\
\hline
\end{tabular}

Note: $* *$ indicates 1 percent level of statistical significance while $*$ indicates 5 percent level of statistical significance. Figures in parentheses are standard deviations.

Further disaggregated results by political system and the MDGs era revealed that Ghana outperformed Nigeria in both policy scenarios. Policies in the democratic system influenced the performance of Ghana in the agricultural production sustainability outcomes. This result is intuitive as Ghana gained independence (in 1957) much earlier than Nigeria's of 1960. Ghana also has longer time of constitutional democratic experience than Nigeria. Although both countries have experienced military incursions in governance, Ghana's current operative constitution is dated back to 1992 while that of Nigeria dates back to 1999. Similarly, the MDGs era significantly influenced agricultural production sustainability outcomes were significantly for Ghana. 
Table 2. Political system and millennium development goals (MDGs) period

\begin{tabular}{lllll}
\hline A. Political System & & & Nigeria & $\begin{array}{l}\text { Better } \\
\text { performing } \\
\text { Period }\end{array}$ \\
& Indicators & Ghana & & country \\
\hline Military & Gross per capita production index & $70.36(11.81)$ & $70.65(11.95)$ & Nigeria \\
& Net Production Index & $36.40(7.33)$ & $41.87(16.77)$ & Nigeria \\
& Net per capita Production Index & $70.26(11.98)$ & $71.22(11.40)$ & Nigeria \\
& Gross Production Index & $36.47(7.40)$ & $41.55(16.89)$ & Nigeria \\
Democracy & Gross per capita production index & $93.55(10.18)$ & $79.42(17.13)$ & Ghana** \\
& Net Production Index & $76.67(34.00)$ & $66.44(34.93)$ & Ghana \\
& Net per capita Production Index & $93.66(10.26)$ & $80.30(16.59)$ & Ghana** \\
& Gross Production Index & $76.62(33.94)$ & $65.85(34.97)$ & Ghana \\
B. Millennium & Development Goals (MDGs) Period & & \\
Pre-MDGs & Gross per capita production index & $75.96(12.42)$ & $68.83(12.41)$ & Ghana* \\
& Net Production Index & $41.27(14.79)$ & $39.04(17.02)$ & Ghana \\
& Net per capita Production Index & $75.96(12.61)$ & $69.61(11.83)$ & Ghana* \\
& Gross Production Index & $41.31(14.85)$ & $38.63(17.15)$ & Ghana \\
& Gross per capita production index & $101.72(7.60)$ & $92.31(5.57)$ & Ghana** \\
MDGs & Net Production Index & $105.43(18.17)$ & $95.73(9.59)$ & Ghana \\
& Net per capita Production Index & $101.79(7.84)$ & $92.81(5.33)$ & Ghana** \\
& Gross Production Index & $105.33(17.88)$ & $95.19(9.49)$ & Ghana \\
\hline
\end{tabular}

Note: $* *$ indicated 1 percent level of statistical significance while $*$ indicates 5 percent level of statistical significance. Figure in parentheses are standard deviations.

\section{Discussion}

Following from the results, the correlates of agricultural production and agricultural production sustainability outcomes were related to policies instruments within the identified policy scenarios which either hampered or helped in specific situation. The policy instruments within these policy scenarios were deemed to be similar but mostly amplified at specific time dimension, democratic regime and the MDGs period. The most significant time period identified was 1961-1980. This result is consistent with past studies that reported significant support for agriculture in Africa within the same period (Birner \& Resnick, 2010; Takeshima \& Liverpool-Tasie, 2015; Mockshell \& Birner, 2015). This same period coincides with the early years of independence when these countries depended largely of foreign exchange from agriculture. This was a period where the agricultural policy focused on taxation of agricultural export commodities (Krueger et al., 1991; Anderson et al., 2013), including cocoa, groundnut and oil palm in Nigeria as well as cocoa in Ghana.

The study also revealed the contributions of the political systems to agricultural production and agricultural production sustainability outcomes. Democratic governance (mostly since 1992 in Ghana and 1999 in Nigeria) influenced significantly the agricultural production and agricultural sustainability outcomes whereby Ghana performed better on the indices. The democratic governance allows citizens to participate in governance. Also leaders and their political parties are often aligned by their manifestos and parliamentary debates that consider the welfare of citizens, including agriculture and food security. Often, the appointment of agricultural policy actors, like ministers and presentation of annual budgets to the parliament, are some of the merits that endear the democratic system of governance. This process is seen to promote transparency and accountability of governments. However, the democratic system is also fraught with the "regime effect" which often results in policy changes from as a result of new political party in power or even within the same political party but different policy actors (Olayide \& Ikpi, 2013).

Contemporary studies indicate that the governments of Ghana and Nigeria (and by extension the political 
systems) have shifted from overtaxing agricultural export commodities like cocoa to provision of subsidies on inputs ((Birner \& Resnick, 2010; Banful \& Olayide, 2010; Mockshell \& Birner, 2015). This policy shift has been extended to import-competing products like rice. Ghana and Nigeria have also implemented structural adjustment programmes that affected the rate of support for agriculture (Brooks et al., 2009: 433). Therefore, what has become obvious from the foregoing is that governments of the two countries are often in dilemma between the policy of agricultural commodity taxation and input subsidy policies. Both Nigeria and Ghana have the history of fertilizer subsidies (Banful \& Olayide, 2010; Benin et al., 2012), including the electronic wallet and input voucher systems (Minot \& Benson, 2009; Takeshima \& Liverpool-Tasie, 2015). It appears that successive governments in Ghana and Nigeria have compromised on both extremes (taxation and subsidy) given the political exigencies of each administration. Overall, the results of the influence of domestic political system point in the direction of positive effect on agricultural production sustainability outcomes.

The influence of the global set of development priorities as entrenched in the MDGs also manifested as correlates of agricultural production and agricultural production sustainability outcomes. The period of the MDGs indicated higher level of improvement in the agricultural production indices than the pre-MDGs era, for both case study countries. For period (2000s) have witnessed increases in the support to agriculture in both countries as a means of transforming the agricultural sector through the transformation agenda. The World Bank (2008) suggested that agriculture-based economies like Ghana and Nigeria could be transformed into industrial economies through the transformation of the economy through the agricultural sector. The influence of the MDGs on the agricultural production and agricultural production sustainability outcomes is an indication of the domestication of the global development agenda - MDGs. This positive influence has implications for the ensuing sustainable development goals (United Nations, 2015).

\section{Conclusion}

The paper submits that a better understanding of the interplay of policy correlates of agricultural production sustainability outcomes can contribute to the current discourse in sustainable development agenda for Africa, and to resolving the dilemma of agricultural policy failures and parlous state of agricultural development especially in Nigeria and Ghana. It reinforces the support for the transformation of agriculture-based economies into sustainable economies through better domestic and implementation of internationally agreed development policy strategies.

Longitudinal data on indices of agricultural production and agricultural production sustainability outcomes were analysed. The results revealed that time trends, political system and the MDGs era significantly influenced agricultural production and agricultural production sustainability outcomes. The differential significance of the policy correlates underscores the implications of each country's policy in promoting sustainable agricultural development which considers present and future agricultural production in the context of growing populations in Nigeria and Ghana. Overall, the results suggest that agricultural production indices and agricultural production sustainability outcomes in Ghana and Nigeria are influenced by political system and implementation of internationally agreed development agenda (as in the case of the MDGs). Hence, it is recommended that agricultural development should be prioritized at both national (country-level) and international level. These finding further reinforce positive potential impacts that global development agenda like the ensuing sustainable development goals (in the post-2015 era) could have on national agricultural development and sustainable agricultural production in Ghana and Nigeria.

\section{Acknowledgements}

This paper is a product of a Postdoctoral Research Fellowship funded by the Department for International Development (DFID), the Association of Commonwealth Universities and the African Academy of Sciences under the Climate Impacts Research Capacity and Leadership Enhancement (CIRCLE) programme (https://www.acu.ac.uk/focus-areas/early-careers/circle/). We are grateful to our universities - the University of Ibadan, Ibadan, Nigeria and Kwame Nkrumah University of Science and Technology, Kumasi, Ghana - for providing conducive environment for research and training. We also express our profound gratitude to anonymous reviewers for useful comments and suggestions that enhanced the quality and content of this paper.

\section{References}

Akinyosoye, V. O. (2005). Government and agriculture in Nigeria: Analysis of policies, programmes and administration. Mcmillian Nigeria. 598 pp.

Anderson, K. (2009). Five decades of agricultural distortions to agricultural incentives. In K. Anderson (Ed.), Distortions to Agricultural Incentives: A Global Perspective, 1955 to 2007 (pp. 3-64). Palgrave Macmillan, 
London and World Bank, Washington, DC.

Anderson, K. (2010). The Political Economy of Agricultural Price Distortions. Cambridge University Press, Cambridge and New York. http://dx.doi.org/10.1017/cbo9780511778964

Anderson, K., \& Masters, W. A. (2009). Distortions to Agricultural Incentives in Africa. World Bank, Washington, DC. http://dx.doi.org/10.1596/978-0-8213-7652-2

Anderson, K., Rausser, G., \& Swinnen, J. (2013). Political economy of public policies: insights from distortions to agricultural and food markets. J. Econ. Lit., 51(2), 423-477. http://dx.doi.org/10.1257/jel.51.2.423

Ayanwale, A. B. (2011). Policy distortions and agricultural output in Nigeria, 1961 - 2006. Final Research Report submitted to African Economic Research Consortium (AERC), Nairobi, Kenya, January, 2011. 71 pp.

Banful, A. B., \& Olayide, O. (2010). Perspectives of Selected Stakeholder Groups in Nigeria on the Federal and State Fertilizer Subsidy Programs. Nigeria Strategy Support Program (NSSP). Report 08, July 2010. International Food Policy Research Institute, Abuja, Nigeria. pp. 14.

Benin, S., Johnson, M., Jimah, K., Taabazuing, J., Tanga, A., Abokyi, E., ... Owusu, V. (2012). Evaluation of Four Special Initiatives of the Ministry of Food and Agriculture, Government of Ghana, Final Report, Accra.

Binswanger, H. P., \& Deininger, K. (1997). Explaining agricultural and agrarian in developing countries policies. Am. Econ. Assoc., 35(4), 1958-2005.

Birner, R., \& Resnick, D. (2010). The political economy of policies for smallholder agriculture. World Dev., 38(10), 1442-1452. http://dx.doi.org/10.1016/j.worlddev.2010.06.001

Böcher, M. (2012). A theoretical framework for explaining the choice of instruments in environmental policy. Forest Pol. Econ., 16, 14-22. http://dx.doi.org/10.1016/j.forpol.2011.03.012

Brooks, J., Croppenstedt, A., \& Aggrey-Fynn, E. (2009). Distortions to agricultural incentives in Ghana. In K. Anderson, \& W. Masters (Eds.), Distortions to Agricultural Incentives in Africa (pp. 413-440). World Bank, Washtington, DC.

DFID, (Department for International Development). (1999). Sustainable Livelihoods Guidance Sheets. Retrieved August 3, 2015, from http://bit.ly/1ucuqLO

Diao, X., Cossar, F., Houssou, N., \& Kolavalli, S. (2014). Mechanization in Ghana: Emerging demand, and the search for alternative supply models. Food Policy, 48, 168-181. http://dx.doi.org/10.1016/j.foodpol.2014.05.013

Dixon, J., Gulliver, A., Gibbon, D., \& Hall, M. (2001). Farming Systems and Poverty: Improving Farmers' Livelihoods in a Changing World. Retrieved from http://bit.ly/1dDekBW

Dorosh, P. A., \& Mellor, J. W. (2013). Why agriculture remains a viable means of poverty reduction in sub-Saharan Africa: The case of Ethiopia. Development Policy Review, 31(4), 419-441. http://dx.doi.org/10.1111/dpr.12013

Federal Government of Nigeria (FGN). (2001). New Agricultural Policy. Federal Ministry of Agriculture and Rural Development, Abuja, Nigeria. 41 pp.

Food and Agricultural Organisation of the United Nations (FAO). (2015). Agricultural Production Indices. Retrieved April 12, 2015, from http://bit.ly/1hfobVd

Garba, P. K. (1999). Does government kee its word? An analysis of the implementation of agricultural policies in Nigeria, 1970-1993. The Nigerian Journal of Economic and Social Studies, 41(3), 421-466.

Garrity, D., Dixon J., \& Boffa, J. (2012). Understanding African Farming Systems: Science and Policy Implications. Food Security in Africa: Bridging Research into Practice. Retrieved from http://bit.ly/1h8lmGJ

Goldstein, J., \& Keohane, R. (1993). Ideas and Foreign Policy: Beliefs, Institutions, and Political Change (1st ed.). Cornell University Press, Ithaca.

Grindle, M., \& Thomas, J. (1989). Policy makers, policy choices, and policy outcomes: the political economy of reform in developing countries. Policy Sci., 22, 213-248. http://dx.doi.org/10.1007/BF00136320

Hazell, P. B. R., \& Ramaswamy, C. (1991). The Green Revolution Reconsidered: The impact of high yielding varieties in south India. Baltimore, MD: Johns Hopkins University Press.

Hazell, P., \& Wood, S. (2008). Drivers of change in global agriculture. Phil. Trans. R. Soc. B., 363, 495-515. 
http://dx.doi.org/10.1098/rstb.2007.2166

Ikpi, A. E. (1995). Policy relevance of research for sustainable development in Nigeria's agriculture. In A. E. Ikpi \& J. K. Olayemi (Eds.), Sustainable agriculture and $\quad$ economic development in Nigeria (pp. 144). Winrock International.

Jayne, T. S., \& Rashid, S. (2013). Input subsidy programs in sub-saharan Africa: a synthesis of recent evidence. Agr. Econ., 44(6), 547-562. http://dx.doi.org/10.1111/agec.12073

Jayne, T., Govereh, J., Mwanaumo, A., Nyoro, J., \& Chapoto, A. (2002). False promise or false premise? The experience of food and input market reform in eastern and Southern Africa. World Dev., 30(11), 1967-1985. http://dx.doi.org/10.1016/S0305-750X(02)00115-8

Kitzes, J., Wackernagel, M., Loh, J., Peller, A., Goldfinger, S., Cheng, D., \& Tea, K. (2008). Shrink and share: humanity's present and future ecological footprint. Phil. Trans. R. Soc. B., 363, 467-475. http://dx.doi.org/10.1098/rstb.2007.2164

Krueger, A. O., Schiff, M., \& Valdés, A. (1991). The Political Economy of Agricultural Pricing Policies. Johns Hopkins University Press, Baltimore and London.

Manyong, V. M., Ikpi, A., Olayemi, J. K., Yusuf, S. A., Omonona, B. T., Okoruwa, V., \& Idachaba, F. S. (2005). Agriculture in Nigeria: Identifying opportunities for increased commercialization and investment. IITA, Ibadan, Nigeria. 159 pp.

Minot, N., \& Benson, T. (2009). Fertilizer subsidies in Africa: Are vouchers the answer? IFPRI Issue Brief 60. July 2009. International Food Policy Research Institute (IFPRI), Washington DC.

Mockshell, J., \& Birner, R. (2015). Donors and domestic policy makers: Two worlds in agricultural policy-making? Food Policy, 55, 1-14. http://dx.doi.org/10.1016/j.foodpol.2015.05.004

MOFA (Ministry of Food and Agriculture). (2007). Food and Agriculture Sector Development Policy (FASDEP II). Republic of Ghana. 77 pages. Retrieved from http://bit.ly/1SWcLnW

Olayide, O. E., \& Ikpi, A. E. (2013). Agricultural production and rural welfare in Nigeria: Assessing agricultural production and rural welfare. Scholars' Press. AV Akademikerverlag GmbH \& Co. KG. Germany. 173pp.

Orren, G. R. (1988). Beyond self-interest. In R. B. Reich (Ed.), The Power of Public Ideas (pp. 13-29). Ballinger Publishing Company, Cambridge, MA.

Pretty, J. (2008). Agricultural Sustainability: concept, principles and evidence. Phil. Trans. R. Soc. B., 447-465. http://dx.doi.org/10.1098/rstb.2007.2163

Sabatier, P., \& Jenkins-Smith, H. C. (1999). The advocacy coalition framework: an assessment. In P. Sabatier (Ed.), Theories of the Policy Process (pp. 117-168). Westview Press, Boulder, CO.

Sebastian, K. (2014). Atlas of African Agriculture Research and Development: Revealing Agriculture's Place in Africa. International Food Policy Research Institute (IFPRI). Washington DC.

Swinnen, J. F. M. (2010). The political economy of agricultural and food policies: recent contributions, new insights, and areas for further research. Appl. Econ. Persp. Pol., 32(1), 33-58. http://dx.doi.org/10.1093/aepp/ppp012

Takeshima, H., \& Liverpool-Tasie, L. S. O. (2015). Fertilizer subsidies, political influence and local food prices in sub-Saharan Africa: Evidence from Nigeria. Food Policy, 54, 11-24. http://dx.doi.org/10.1016/j.foodpol.2015.04.003

United Nations. (2015). Transforming Our World: The 2030 Agenda for Sustainable Development. United Nations Sustainable Development Solution Network (UN-SDSN), USA. Retrieved from http://unsdsn.org

Van de Walle, N. (2001). African Economies and the Politics of Permanent Crisis, 1979-1999. Cambridge University Press, Cambridge. http://dx.doi.org/10.1017/CBO9780511800344

World Bank. (2008). World Development Report (WDR) 2008. Agriculture for development. The World Bank, Washington, DC. 386 pp.

\section{Copyrights}

Copyright for this article is retained by the author(s), with first publication rights granted to the journal.

This is an open-access article distributed under the terms and conditions of the Creative Commons Attribution license (http://creativecommons.org/licenses/by/3.0/). 